\title{
Microbiological quality in Finnish public swimming pools and whirlpools with special reference to free living amoebae: a risk factor for contact lens wearers?
}

\author{
Minna Vesaluoma, Seija Kalso, Liisa Jokipii, David Warhurst, Antti Pönkä, Timo Tervo
}

Department of Ophthalmology, Helsinki University Central Hospital, Helsinki, Finland M Vesaluoma

T Tervo

Helsinki City Center of the Environment, Helsinki, Finland

$S$ Kalso

A Pönkä

Department of Serobacteriology, University of Helsinki, Helsinki, Finland L Jokipii

London School of Hygiene and Tropical Medicine, London, UK D Warhurst

Correspondence to: Dr Timo Tervo, Department of Ophthalmology, Helsinki University Central Hospital Haartmaninkatu 4 C, FIN00290 Helsinki, Finland.

Accepted for publication 5 September 1994

\begin{abstract}
To assess the possible risk of microbial keratitis associated with swimming or bathing in public pools, the microbiological quality as well as the presence of free living amoebae in 16 halogenated swimming pools and whirlpools, located in Helsinki, Finland, was determined. Five additional whirlpools situated in the ferries cruising from Finland to Sweden were included in the study. Other parameters investigated were the total bacterial count, identification of Pseudomonas aeruginosa and Staphylococcus aureus, measurement of free residual and combined chlorine, potassium permanganate index, urine, $\mathrm{pH}$, and turbidity. Amoebae were detected in $41 \%$ of the pool water samples studied. Seven of 11 whirlpools and four of 10 swimming pools were shown to contain amoebae. An Acanthamoeba species was isolated from only one outdoor swimming pool; the other amoebae belonged to the genera Vexillifera, Flabellula, Hartmannella, and Rugipes. Although not a single verified case of Acanthamoeba keratitis has been found in Finland, the findings show that there is a theoretical risk of amoebic and bacterial keratitis associated with swimming or bathing in properly cleaned public pools. Consequently, we do not recommend swimming or bathing with contact lenses. (Brf Ophthalmol 1995; 79: 178-181)
\end{abstract}

Epidemiological evidence has indicated that bathing or swimming in polluted waters is a potential health risk. ${ }^{1-4}$ Infections transmitted by swimming pool or whirlpool water most probably result from inadequate cleaning and/or disinfection measures. ${ }^{5-7}$ The microorganisms detectable in pool water originate from the skin, mucous membranes, and clothing of bathers as well as from the environment. Most agents are non-pathogenic, but some are able to cause infections.

Pseudomonas aeruginosa and Staphylococcus aureus most frequently cause ocular, aural, or cutaneous infections related to swimming. ${ }^{89}$ $P$ aeruginosa has caused aural and urogenital infections due to bathing in whirlpools. ${ }^{10}$ $S$ aureus and $P$ aeruginosa are also frequently found in contact lens associated keratitis. ${ }^{11}$

Diseases caused by free living amoebae - for example, potentially fatal Naegleria fowleri meningoencephalitis, are also often transmitted while swimming in chlorinated swimming pools. ${ }^{1213}$ Certain free living amoebae are able to cause severe sight threatening keratitis, the treatment of which may last for months yet fail, making corneal transplantation necessary. ${ }^{14}$ The life cycle of Acanthamoeba consists of two different stages: active trophozoite and inactive cyst. The encysted form is relatively resistant to unfavourable conditions - for example, drugs and disinfectants. The trophozoite form of Acanthamoeba adheres to all lens types, but the encysted form does not seem to attach to gas permeable hard lenses. ${ }^{15}$ Acanthamoebae are able to contaminate contact lens solutions and storage cases. ${ }^{1617}$ Even commercial antimicrobial lens care solutions have been found to contain acanthamoebae. ${ }^{1819}$ No diagnosed cases of Acanthamoeba keratitis have yet occurred in Finland, ${ }^{20}$ although a few patients have been treated in Sweden ${ }^{21}$ and Norway. ${ }^{22}$ Recently also Vahlkampfia/Hartmannella amoebae have been isolated from both the cornea and the contact lens case of a patient with keratitis, as well as from the tap water the patient had used. ${ }^{23}$ To clarify the risk of exposure when swimming or bathing with contact lenses we investigated the presence of amoebae in swimming pools and whirlpools in the Helsinki area and in ferries cruising from Finland to Sweden.

Materials and methods

Most of the 10 swimming pools and 11 whirlpools studied were supplied with public tap water from a single origin, the city of Helsinki. The five whirlpools on the ferries were supplied with water either from Helsinki or Stockholm. The water of Helsinki was treated by routine methods: flocculation, decantation, filtration, and disinfection by chlorine and ozone. Filtering and the use of sodium hypochlorite as a disinfectant were the principal measures used in the pools studied.

One litre water samples were drawn into sterile bottles from the surface and/or from a depth of $20 \mathrm{~cm}$ of each swimming pool and whirlpool for amoebal isolation. A total of 34 samples were taken, 22 from whirlpools (two from each pool), and 12 from swimming pools (two pools were examined twice). Fifty $\mathrm{ml}$ portions of water were centrifuged $(1000 \mathrm{~g}$ for 10 minutes) and the sediments then centrifuged together in one batch.

To study the surface contamination of the 
Table 1 Bacteriological and chemical analyses of whirlpool and swimming pool water. (Number of samples 26)

\begin{tabular}{|c|c|c|c|c|}
\hline Parameter & Mean & Median & Range & Guide level \\
\hline $\begin{array}{l}\text { Total plate count }(\mathrm{cfu} / \mathrm{ml}) \\
\text { Combined chlorine }(\mathrm{mg} / \mathrm{l}) \\
\text { Free chlorine }(\mathrm{mg} / \mathrm{l}) \\
\text { Total chlorine }(\mathrm{mg} / \mathrm{l}) \\
\text { pH } \\
\text { Potassium permanganate index }(\mathrm{mg} / \mathrm{l}) \\
\text { Turbidity (FTU) } \\
\text { Urine (mg/l) }\end{array}$ & $\begin{array}{l}131 \\
0 \cdot 44 \\
0 \cdot 59 \\
1 \cdot 03 \\
7 \cdot 1 \\
8 \cdot 4 \\
0 \cdot 62 \\
0 \cdot 60\end{array}$ & $\begin{array}{l}3 \\
0 \cdot 30 \\
0 \cdot 35 \\
0 \cdot 75 \\
7 \cdot 2 \\
6 \cdot 0 \\
0 \cdot 21 \\
0 \cdot 30\end{array}$ & $\begin{array}{l}0-3000 \\
0 \cdot 05-1 \cdot 5 \\
<0 \cdot 05-3 \cdot 3 \\
0 \cdot 25-4 \cdot 8 \\
3 \cdot 9-9 \cdot 1 \\
1 \cdot 4-23 \\
0 \cdot 09-5 \cdot 9 \\
<0 \cdot 1-2 \cdot 5\end{array}$ & $\begin{array}{l}<100 \\
\quad 00 \cdot 5 \\
\geqslant 0 \cdot 5^{\star} \\
<3 \cdot 0 \\
7 \cdot 0-7 \cdot 2 \\
<10 \\
<0 \cdot 4 \\
<1 \cdot 0\end{array}$ \\
\hline
\end{tabular}

*Whirlpool $\geqslant 0.5 \mathrm{mg} / 1$, swimming pool $\geqslant 0.3 \mathrm{mg} /$, when $\mathrm{pH} 6 \cdot 5-7 \cdot 2$.

tWhirlpool $<3.0 \mathrm{mg} / \mathrm{l}$, swimming pool $<2.5 \mathrm{mg} /$.

FTU = formazine turbidity units. also high. Neither faecal coliforms nor $S$ aureus were detected in the samples examined.

Amoebae were detected in 14 of the 34 samples examined (41\%; Table 2). Four of the positive samples were obtained from swimming pools and seven from whirlpools. Acanthamoeba was isolated from only one outdoor swimming pool; the other isolates belonged to the genera Vexillifera, Flabellula, Hartmannella, and Rugipes. The majority $(71 \%)$ of the amoebae were detected in pools in which the bacteriological quality of the water was good. Both samples containing $P$ aeruginosa were also amoeba positive. No amoebae were found in the swab samples from the walls of the pools.

The free chlorine concentration was below the guide level in $46 \%$ of the samples and amoebae were detected in $67 \%$ of these samples. On the other hand, amoebae could also be found in samples in which the free chlorine residue was as high as $3.3 \mathrm{mg} / \mathrm{l}$. Free chlorine reacts with impurities in water to form combined chlorine. In $27 \%$ of the water samples the concentration of combined chlorine and the amount of organic matter (oxygen consuming substances) were elevated. Of the amoeba positive water samples $36 \%$ did not conform to the requirements and recommendations stated for good quality of swimming water. However, no correlation was seen between the degree of general quality of swimming water and the amoebal findings. Detroit, Michigan, USA, at $35^{\circ} \mathrm{C}$ for 48 hours) and faecal coliforms (the most probable number method using lactose bromocresol purple broth at $44.5^{\circ} \mathrm{C}$ for 48 hours) using standard Finnish procedures. ${ }^{26} 27$ The presence of $P$ aeruginosa in $100 \mathrm{ml}$ of water was examined, using the procedure of American Public Health Association (APHA). ${ }^{28}$ The samples were also filtered for the isolation of $S$ aureus, using M-5-LSMA agar. ${ }^{29}$

Other investigations included the colorimetric determination of chlorine, ${ }^{28}$ measurement of $\mathrm{pH}$ and turbidity, using a Methrohm $605 \mathrm{pH}$ meter (Herisan, Switzerland) and a Hach Model 2100 A turbidimeter (Hach Chemical Company, Iowa, USA). The potassium permanganate index was used to describe the amount of organic matter. ${ }^{30}$ The water urine concentration was determined by a spectrometric method. ${ }^{31}$

\section{Results}

Table 1 summarises the data of the microbiological and chemical analyses. The microbiological quality of the water was good (less than $100 \mathrm{bacteria} / \mathrm{ml}$ ) in $90 \%$ of the pools. $P$ aeruginosa was detected in the water of two whirlpools in which the total bacterial count was

Table 2 Frequency of amoebic contamination in whirlpools and swimming pools

\begin{tabular}{llllll}
\hline & \multicolumn{2}{l}{ Water samples $(n=34)$} & & Pools $(n=21)$ \\
\cline { 2 - 3 } \cline { 5 - 6 } Pool & $\begin{array}{l}\text { Amoeba } \\
\text { present }\end{array}$ & $\begin{array}{l}\text { Amoeba } \\
\text { absent }\end{array}$ & & $\begin{array}{l}\text { Amoeba } \\
\text { present }\end{array}$ & $\begin{array}{c}\text { Amoeba } \\
\text { absent }\end{array}$ \\
\hline Whirlpool & 10 & 12 & & 7 & 4 \\
Swimming pool & 4 & 8 & & 4 & 6 \\
Total & 14 & 20 & & 11 & 10 \\
\hline
\end{tabular}

\section{Discussion}

There are about 20 known species of acanthamoebae; at least five have been reported to cause corneal infection: $A$ castellanii, $A$ culbertsoni, $A$ hatchetti, $A$ polyphaga, and $A$ rhysodes. ${ }^{32}$ Acanthamoebae are ubiquitous in soil, water and dust. They have been isolated from freshwater, sea water, tap water, bottled mineral water, air, air conditioners, contact lens cases, and contact lens solutions. ${ }^{33}$ Air, dust, and soil carried by swimmers into the water may be the sources of acanthamoebae. Contact lens wearers constitute $85 \%$ of the patients, and a history of exposure to contaminated water is common among the diseased. ${ }^{34}$ Wearers of both disposable soft lenses ${ }^{35} 36$ and hard contact lenses ${ }^{37}$ also exist among the affected individuals. Acanthamoeba keratitis is predominantly related to daily or extended wear soft contact lenses. ${ }^{34}$

The quality of the tap water used for the filling of the pools reflects the efficiency of the water treatment process. When water samples from the home environment of 50 contact lens wearers were studied, Acanthamoeba species were isolated from six bathroom cold water taps. ${ }^{18}$ Also other amoebae, including Hartmannella, Naegleria, Vahlkamfia, Vanella, Vexillifera, Platyamoeba, Filamoeba, and Nucleria, were identified. Colonisation of amoebae most probably occurs in those parts of water distribution systems where the residual concentrations of disinfectant are low and water delay long. Poorly maintained and 
old water distribution systems may also be favourable for growth in the tap water.

The mean value of total chlorine concentration of the tap water used for filling of the pools was $0.5 \mathrm{mg} / \mathrm{l}$. Even a free chlorine concentration of $4 \mathrm{mg} / 1$ does not destroy the Acanthamoeba cysts after 3 hours of exposure. ${ }^{38}$ The tap water distributed by the city of Helsinki fulfils the microbiological requirements for drinking water of directive EEC 778/80: the absence of coliform bacteria and the number of total count of bacteria less than $10 / \mathrm{ml}$ (at $22^{\circ} \mathrm{C}$ for 48 hours). The maximal allowed chlorine concentration $(1 \mathrm{mg} / \mathrm{l})$ in drinking water ${ }^{39}$ is, however, not high enough to destroy the amoebae. Any contamination of the water pipelines with soil or sewage water can pollute the system with free living amoebae.

Filtering and disinfection with sodium hypochlorite are the principal cleaning measures used in the pools studied. These procedures are also unable to destroy amoebae (mainly cysts). ${ }^{40}$ Filters retain particles suspended in water and amoebae can proliferate in the filter. Consequently, the filters should be washed regularly, using a reverse flux.

Amoebae ingest bacteria. Bacterial cocontamination may enhance amoebic pathogenicity according to in vitro and in vivo studies. ${ }^{41} 42$ In this study we observed no correlations between either the concentration of bacteria or the amount of organic matter and the occurrence of amoebae. Organic particles tend to accumulate as limescale on the pool walls and thus may concentrate the growth of amoebae. However, we found no amoebae on the walls of the pools.

An Acanthamoeba species was found in only one outdoor swimming pool in Helsinki. It is most probably introduced by a swimmer and not through the water supply. The other strains isolated belonged to the genera Vexillifera, Flabellula, Hartmannella, and Rugipes. However, most of the pools received their water from a single source. Further studies are needed to clarify if Acanthamoeba is more common in other parts of the country. The cleaning and disinfection methods of Helsinki are probably the best in Finland. Consequently, it is likely that the quality of water is worse elsewhere in Finland where the cleaning measures are less advanced. The finding shows that although the disinfection methods used - for example, ozonisation, may be more effective than those used in some other cities they do not completely eliminate the risk of amoebal contamination. Patients having their corneal/tear fluid infection barriers compromised - for example, by contact lens wear ${ }^{34}$ or mild surface trauma, ${ }^{43}$ may then have higher risks of amoebic keratitis. Contact lens soaking solutions and lens cases can serve as reservoirs for multiplication of many bacteria and fungi. ${ }^{1744}$ Earlier studies have already shown the association of Acanthamoeba keratitis with the use of tap water or homemade saline for contact lens disinfection. ${ }^{45}$ The elevated risk of bacterial infection associated with contaminated pool water is also shown in this study. Consequently, contact lenses should not be worn when swimming or bathing in public pools.

We thank Juhani Airo, MSc, for the chemical water analyses. We are also grateful to Anita Mutanen, Helga Heikura, and Salme Saareila for analyses of the samples. This work was supported by the Scientific Foundation of Instrumentarium Ltd and the Sigrid Juselius Foundation.

1 Cabelli VJ, Dufour AP, McCabe LJ, Levin MA. Swimmingassociated gastroenteritis and water quality. $A m$ f Epidemiol 1982; 115: 606-16.

2 Seyfried PL, Tobin RS, Brown NE, Ness PF. A prospective study of swimming-related illness. I. Swimming-associated health risk. Am $\mathcal{f}$ Public Health 1985; 75: 1068-70.

3 Seyfried PL, Tobin RS, Brown NE, Ness PF. A prospective study on swimming-related illness. II. Morbidity and the microbiological quality of water. Am $\mathscr{f}$ Public Health 1985; 75: 1071-5.

4 Balarajan R, Soni Raleigh V, Yuen P, Wheeler D, Machin $D$, Cartwright $R$. Health risks associated with bathing in sea water. $B M \mathcal{F}$ 1991; 303: 1444-5.

5 Jorgense PH. Transmission of viruses in public swimming pools. Vatten 1985; 41: 179-85.

6 Ratnam S, Hogan K, March SB, Butler RW. Whirlpoolassociated folliculitis caused by Pseudomonas aeruginosa: report of an outbreak and review. $\mathcal{f}$ Clin Microbiol 1986; 23: 655-9.

7 Lenaway DD, Brockmann R, Dolan GJ, Cruz-Uribe F. An outbreak of an enterovirus-like illness at a community outbreak of an enterovirus-like illness at a community
wading pool: Implications for public health inspection wrograms. Am $\mathcal{f}$ Public Health 1989; 79: 889-90.

8 Kosatsky T, Kleeman J. Superficial and systemic illness related to a hot tub. Am $\mathcal{F}$ Med 1985; 79: 10-2.

9 Herwaldt BL, Craun GF, Stokes SL, Juranek DD. Waterborne disease outbreaks 1989-1990. MMWR 1991; 40: $1-21$.

10 Havelaar AH, Bosman $M$, Borst $J$. Otitis externa by Pseudomonas aeruginosa associated with whirlpools. f Hyg 1983; 90: 489-98.

11 Alfonso E, Mandelbaum S, Fox MJ, Forster RK. Ulcerative keratitis associated with contact lens wear. $A m \mathcal{f}$ keratitis associated with con

$12 \mathrm{De}$ Jonckheere JF. Studies on pathogenic free-living amoebae in swimming pool. Bull De L'Institut Pasteur 1979; 77: 385-92.

13 Visvesvara GS, Stehr-Green JK. Epidemiology of free-living amoeba infections. F Protozool 1990; 37: 25S-33S.

14 Ficker L. Acanthamoeba keratitis - the quest for a better diagnosis. Eye 1988; 2 (suppl): 37-45.

15 Kilvington S, Larkin DFP. Acanthamoeba adherence to contact lenses and removal by cleaning agents. Eye 1990; 4: 589-93.

16 Larkin DFP, Kilvington S, Easty DL. Contamination of contact lens storage cases by Acanthamoeba and bacteria. contact lens storage cases by Acanth

17 Devonshire P, Munro FA, Abernethy C, Clark BJ. Microbial contamination of contact lens cases in the west of Scotland. Br f Ophthalmol 1993; 77: 41-5.

18 Seal D, Stapleton F, Dart J. Possible environmental sources of Acanthamoeba spp in contact lens wearers. $\mathrm{Br} \mathcal{F}$ Ophthalmol 1992; 76: 424-7.

19 Silvany RE, Dougherty JM, McCulley JP. Effect of contact lens preservatives on Acanthamoeba. Ophthalmology 1991; 98: 854-7.

20 Tervo T, Louhija J, Jokipii L, Tervo K, Jokipii A Akantameeba keratiiti - uusi hankala sarveiskalvosairaus. Akantameeba keratiiti - uusi ha
Suom Lääkril 1988; 5: 1991-3.

21 Stenevi U, Floren I, Miörner H. Acanthamoeba-keratit en ny diagnos i Sverige. Läkartidningen 1992; 89: 127-8.

22 Aasly K, Bergh K. Acanthamoeba keratitis; report of the first Norwegian cases. Acta Ophthalmol (Copenh) 1992; 70: 698-701.

23 Kirkness C, Aitken D, Gavin M, Hay J, Lee W, Seal D. Vahlkampfid keratitis simulating Acanthamoeba infection, associated with disposable contact lens wear. (An overlooked diagnosis?) Invest Ophthalmol Vis Sci 1993; 34 (suppl): 853 .

24 Page F. Taxonomic criteria for limax amoebae, with descriptions of 3 new species and 3 of Vahlkampfia. Protozool 1967; 14: 499-52

25 Page F. A further study of taxonomic criteria for limax amoebae with descriptions of new species and a key to genera. Arch Protistenk Bd 1974; 116: 149-84.

26 SFS 4112: Veden pH:n mittaaminen. Suomen Standardoimisliitto, Helsinki, Finland, 1974

27 SFS 4088: Veden lämpökestoisten (fekaalisten) koliformisten bakteerien lukumäärän määritys kalvosuodatusmenetelmällä. Suomen Standardoimisliitto, Helsinki, Finland, 1988 .

28 APHA. Standard methods for the examination of water and wastewater. 17 th ed. Washington, 1989.

29 Stengren SR, Starzyk MJ. A modified medium for the recovery of Staphylococcus from water. Microbios 1984; 41: recovery $191-203$.

30 Anon. Juoma - ja talousveden tutkimusmenetelmät. Elintarviketutkijaseura. Helsinki, Finland, 1969.

31 Koroleff F. Meriveden yleisimmät kemialliset analyysiKoroleff F. Meriveden yleisimmät kemialliset analyysi-
menetelmät. Merentutkimuslaitos, Helsinki, Finland, 1979. 
32 Ma P, Visvesvara GS, Martinez AJ, Theodore FH, Daggett PM, Sawyer TK. Naegleria and Acanthamoeba infections: review. Rev Infect Dis 1990; 12: 490-513.

33 De Jonckheere JF. Ecology of Acanthamoeba. Rev Infect Dis 1991; 13 (suppl 5): S385-7.

34 Stehr-Green JK, Bailey TM, Visvesvara GS. The epidemiology of Acanthamoeba keratitis in the United States. Am $\mathcal{F}$ Ophthalmol 1989; 107: 331-6.

35 Heidemann DG, Verdier DD, Dunn SP, Stamler JF. Acanthamoeba keratitis associated with disposable contact Acanthamoeba keratitis associated with dispos

36 Sarwar N, Griffith GAP, Loudon K, Tullo AB. Acanthamoeba keratitis associated with disposable hydroAcanthamoeba keratitis associated with disposable hydro-
gel contact lenses disinfected daily with a chlorine-based gel contact lenses disinfected daily with a chlorine-

37 Lang GE, von Heimburg-Elliger A. Akanthamöben-Keratitis bei Trägerin harter Kontaktlinsen. Klin Monatsbl Augenheilkd 1991; 198: 290-4.

38 De Jonckheere JF, van de Voorde H. Differences in destruction of cysts of pathogenic and nonpathogenic Naegleria and Acanthamoeba by chlorine. Appl Environ Microbiol 1976; 31: 294-7.
39 Lääkintöhallitus. Yleiskirje nro 1977. Talousveden terveydellisen laadun valvonta. Helsinki, Finland, 1990

40 Jarrol EL, Bingham AK, Meyer EA. Effect of chlorine on Giardia lamblia cyst viability. Appl Environ Microbiol 1981; 41: 483-7.

41 Bottone EJ, Madayag RM, Qureshi MN. Acanthamoeba keratitis: synergy between amebic and bacterial cocontaminants in contact lens care systems as a prelude to infection. f Clin Microbiol 1992; 30: 2447-50.

42 Badenoch PR, Johnson AM, Christy PE, Coster DJ. Pathogenicity of Acanthamoeba and a corynebacterium in Pathogenicity of Acanthamoeba and a corynebacterium

43 Jones DB, Visvesvara GS, Robinson NM. Acanthamoeba polyphaga keratitis and Acanthamoeba uveitis associated with fatal meningoencephalitis. Trans Ophthal Soc UK 1975; 95: 221-31.

44 Donzis PB, Mondino BJ, Weissman BA, Bruckner DA. Microbial contamination of contact lens care system. Am $\mathcal{f}$ Ophthalmol 1987; 104: 325-33.

45 Stehr-Green JK, Bailey TM, Brandt FH, Carr JH. Acanthamoeba keratitis in soft contact lens wearer. $\mathcal{F} A M A$ 1987; 258: 57-60.

\section{History of ophthalmology}

\section{The fifteenth century ophthalmologist's vade mecum}

Benvenutus Grassi was probably born in the eleventh century, and wrote a practical text of ophthalmology which was popular for 500 years. For general surgeons such as Guy de Chauliac, it was the standard ophthalmological vade mecum.

Both copied manuscripts and printed copies survive, including Provençal, French, Hebrew, and English translations from the Latin. The book was modestly priced, and most barber surgeons probably owned a copy. Let us try to get the gist of what we would have learned from it, if we were apprentice ophthalmologists in the 1400 s.

'Regarding anatomy, dear reader, the eye consists of two coats, filled with humours which are albugineous (like egg white) - and vitreous (like glass) respectively. The spirit of sight enters through the pupil and flies down the optic nerve.

'You will see much cataract. There are three curable and four incurable types. One is caused by excessive eating and drinking, and others by "severe headache, too much worry, weeping and wailing". Some physicians use purgation and powders, yet this is useless. Cataract is a disease within the eye and the cure must directly reach this area. (NB: Benvenutus has no use for diplomacy, referring to these practitioners as either ignorant physicians' or 'fools of quacks', depending on the translation.)

'Treat cataract by couching - purge the patient and have him sit astraddle a bench. Face him, and with a silver needle, pierce the eye coats. Hold the cataract down from exactly the length of time it takes you to say four pater nosters. Postoperatively, patients must lie still for eight days while egg white dressings are applied. They must have a light diet, and no chicken, as this causes rushing of blood to the eyes. Do not use steel instruments. The point can break and remain within the globe, and severe pain, cold abscess, and loss of sight will result. Gold needles are good, gold having inherent power over cold and dampness (basic astrology was common knowledge among the educated, the sun being the gold planet, source of life and warmth and banisher of cold and fog).

'Ophthalmia is a disease which shows itself on the white of the eye, accompanied by burning and discomfort. Your patient will be tormented, and will not be able to sleep or rest due to a feeling of sand in the eye. To treat him, equal parts or hyacinth extract and sarcol (the gum of a certain tree) should be mixed in a brass mortar and dusted over the eye of the reclining patient. Do not, dear friends, use nostrums which aggravate the patient's suffering. These can cause the contents of the eye to run out between the lids, followed by blindness. In chronic ophthalmia, mix one ounce each of oak fern, milkweed, and rhubarb with one drachm each of crocus, cubebs, and cinnamon. Administer morning and evening.

'Regarding fungus, you will see patients with a fleshy growth between the nose and eyes, which some call "mulberry". The swelling looks rather like lung substance, and is granular. It may involve both lids, and if you seize it with a hook it tears through. To cure it, cut it away with a sharp knife, cauterise the wound with a hot iron and dress with cotton soaked in egg white.

'Injuries from sticks, stones, and fists are common. Apply beaten albumen on a cotton pad, and do this hastily, before the ocular humours escape! Renew this four times daily, and twice during the night. Meanwhile, anoint the patient's forehead and temples with alabaster ointment. If the coats of the eye are severely lacerated, more potent cure is needed: remove the embryos from white hen's eggs, beat them in a mortar to the consistency of ointment and apply twice daily.

'Always remember that organs are preserved by agents that resemble them - the eye is a cold organ, so use cold remedies. Patients have lost their sight from use of absinthe and frankinsence which are heating agents. An excellent general remedy is the juice of fennel, rue, verbena, and sage mixed with the urine of a chaste youth. This is a powerful treatment - use it and you will believe!' 'I have made much money by many of these cures,' remarks the author proudly.

Benvenutus's last piece of advice is this: do not forget the poor if you want God to give you success operating!

FIONA ROMAN

Wood CA. Benvenutus Grassus - De Oculis. Stanford University Press, 1929. 